\title{
Urocortin-like immunoreactivity in the primary lymphoid organs of the duck (Anas platyrhynchos)
}

\author{
A. De Luca, ${ }^{1}$ C. Squillacioti, ${ }^{1}$ M.E. Pero, ${ }^{1}$ S. Paino, ${ }^{2}$ E. Langella, ${ }^{2}$ N. Mirabella ${ }^{1}$ \\ ${ }^{1}$ Department of Structures, Functions and biological Technologies, University of Naples Federico II, \\ Napoli; ${ }^{2}$ Department of Sciences of Animal Production, University of Basilicata, Italy
}

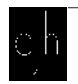

(C2009 European Journal of Histochemistry

Urocortin (UCN) is a 40 aminoacid peptide which belongs to corticotropin-releasing factor (CRF) family. This family of peptides stimulates the secretion of proopiomelanocortin (POMC)-derived peptides, adrenocorticotropic hormone (ACTH), $\beta$-endorphin and melanocyte-stimulating hormone $(\mathrm{MSH})$ in the pituitary gland. In the present study, using Western blotting and immunohistochemistry, the distribution of UCN in the primary lymphoid organs of the duck was investigated at different ages. In the cloacal burse and thymus, Western blot demonstrated the presence of a peptide having a molecular weight compatible with that of the mammalian UCN. In the cloacal burse, immunoreactivity was located in the medullary epithelial cells and in the follicular associated and cortico-medullary epithelium. In the thymus, immunoreactivity was located in single epithelial cells. Double labelling immunofluorescence studies showed that UCN immunoreactivity completely colocalised with cytokeratin immunoreactivity in both the thymus and cloacal burse. Statistically significant differences in the percentage of UCN immunoreactivity were observed between different age periods in the cloacal burse. The results suggest that, in birds, urocortin has an important role in regulating the function of the immune system.

Key words: cloacal burse, thymus, cytokeratin, medullary reticular epithelial cells, CRF

Correspondence: Adriana De Luca,

University of Naples Federico II, Napoli, Italy

Tel.: +39.081.2536114.

Fax +39.081 .2536097 .

E-mail: adrideluca@unina.it

Paper accepted on July 22, 2009

European Journal of Histochemistry

2009; vol. 53 issue 3 (July-September): 167-176
U rocortin (UCN) is a 40-amino acid peptide belonging to the mammalian corticotropinreleasing hormone ( $\mathrm{CRH}$ ) family which was first discovered in the rat midbrain (Vaughan et al., 1995). On the basis of its selective ability to bind $\mathrm{CRH}$-receptor type 2 (CRH-R2), different types of UCN, i.e. UCN1, UCN2 and UCN3, have been identified (Lewis et al., 2001; Reyes et al., 2001). In mammals, UCN has been found in the central nervous (Vaughan et al., 1995), digestive (Muramatsu et al., 2000) and immune systems (Bamberger et al., 1998; Kageyama et al., 1999; Baigent et al., 2000), and in genital organs (Petraglia et al., 1996). UCN has also been found to play a role in regulating some $\mathrm{CRH}$-receptormediated effects (Turnbull et al., 1999). While UCN2 and UCN3 selectively bind to CRH-R2, UCNI binds to both CRH-RI and CRH-R2 and shows a greater affinity to $\mathrm{CRH}-\mathrm{R} 2$ than $\mathrm{CRH}$ alone (Chalmers et al., 1996). Despite the ability to interact with the same receptors, different functions are attributed to UCN and CRH. CRH is the primary neuroregulator of the vertebrate stress response in so far as it has been shown to be the major hypothalamic releasing factor for pituitary adrenocorticotropic hormone, whereas UCN seems not to be involved in the activation of the hypothalamus- hypophysis-adrenal axis (Turnbull et al., 1999). Conversely, UCN influences the function of the cardiovascular and nervous systems by increasing anxiety, decreasing appetite and influencing behavioral activity (Latchman, 2001). In non-mammalian vertebrates, few data have been reported on the presence and the role of UCN. The molecule, however, may have been conserved during vertebrate evolution, given that it has also been detected in amphibians and birds (Kozicz et al., 2002; Cavani et al., 2003; Boorse et al., 2005; Calle et al., 2005). In amphibians, UCN and CRH receptors have been found in the brain as well as 
in many other organs and tissues, including the pituitary gland, heart, kidney and alimentary canal (Kozicz et al., 2002; Boorse et al., 2005, 2006); thus suggesting a potential role for diverse actions in tissue maintenance and function. In Xenopus laevis, UCN injected in the third ventricle has been found to suppress food intake (Boorse et al. 2005). Moreover, it has been found to act as a cytoprotective factor in tadpole tail during metamorphosis (Boorse et al. 2006). In birds, UCN-ir has been found in neurons of the pigeon paramedian subgriseal mesencephalon which appear to be part of the brain circuitry involved in sympathetic nervous system-mediated behavioral responses to stress (Cavani et al. 2003; Cunha et al., 2007). Intracerebroventricular administered UCN, moreover, has been reported to decrease food intake in the chicken (Zhang et al., 2001). Up until now, however, no data are available regarding the presence and role of UCN in tissues and organs of birds outside the central nervous system (CNS). Since UCN and its receptors have been reported to be extensively expressed in immune tissues and addressed to play important roles in the regulation of the immune response (Baigent, 2001), the present study has investigated the presence and distribution of UCN in the primary lymphoid organs of the duck by means of Western blotting and immunohistochemistry. In addition, in order to verify if UCN also plays a role in the maturation of bird primary lymphoid organs, UCN expression was evaluated at different age periods.

\section{Materials and Methods}

\section{Animals and tissue collection}

Campbell khaki ducks (Anas platyrhynchos), of both sexes, were used. They were anaesthetized by intramuscular injection of ketamine $(25 \mathrm{mg} / \mathrm{kg}$ ) and then killed by exsanguination. Thymus and cloacal burse from 10-, 30-, 50-, 70-, 90-, 110-, 140- and 170-day-old ducks were collected. From each thymus three lobes (one from cranial, one from median and one from caudal portion) were utilized. Five animals for each group were used. Three adult Sprague-Dawley rats (13 weeks of age; body weight: $380 \pm 20 \mathrm{~g}$; purchased from Harlan Italy) were used. They were housed in temperature- and lightcontrolled rooms and were given water ad libitum. Three frogs ( $R$. esculenta), captured in the vicinity of Naples were used. Rats were anaesthetised by intraperitoneal injection of urethane $(1.2 \mathrm{~g} / \mathrm{kg})$, frogs by immersion in a MS222 solution (Sigma Chemical Co., St. Louis, MO). Both rats and frogs were killed by decapitation and brains were collected. All procedures were approved by Italian laws regarding animal use in research (art. 7 D.Lgs. 116/92).

\section{Western blotting}

Fresh pieces of duck thymus and cloacal burse, frog brain and rat brain were collected, frozen on dry ice and stored at $-80^{\circ} \mathrm{C}$ until extraction. Aliquots of thymus, cloacal burse, frog brain and rat brain extracts were lysed in ice cold-homogenization buffer, containing 2\% Triton X-100, 150 $\mathrm{mM} \mathrm{NaCl}, 50 \mathrm{mM}$ Tris $\mathrm{HCl}, \mathrm{pH} 7.00,5 \mathrm{mM}$ EDTA, $1 \mathrm{mM} \mathrm{PMSF}, 10 \mu \mathrm{g} / \mathrm{mL}$ leupeptin and 0.1 $\mathrm{U} / \mathrm{mL}$ aprotinin. After $30 \mathrm{~min}$ on ice, lysates were clarified by centrifugation at $10000 \mathrm{xg}$ for $10 \mathrm{~min}$ at $+4^{\circ} \mathrm{C}$. The resulting supernatants were characterised for protein concentration by Bio-Rad DC protein assay. Equal amounts of proteins were immunoprecipitated overnight at $4^{\circ} \mathrm{C}$ with antiUrocortin antibody (cod. sc-1825, Santa Cruz Biotechnologies, Santa Cruz, CA, USA) ( $1 \mu \mathrm{g} / 100$ $\mu \mathrm{g}$ proteins) previously bound to protein $\mathrm{A} / \mathrm{G}$ Agarose (Santa Cruz Biotechnologies, Santa Cruz, CA, USA). The primary antibody was an affinity-purified goat polyclonal antibody raised against a peptide corresponding to amino acids 102-121 mapping at the carboxy terminus of rat urocortin precursor which is 122-amino acid protein with a carboxy terminus including a putative 40-amino acid peptide (Donaldson et al., 1996; Vaughan et al., 1995). Beads were sedimented by brief centrifugation and washed extensively with ice-cold homogenization buffer. Proteins, synthetic peptide UCN (cod U6631 Sigma, St Louis, M0, USA) and syntetic peptide CRF ( cod C3042 Sigma), solubilised in boiling SDS sample buffer (2\% SDS, 5\% L-mercaptoethanol, 66 mM Tris, $\mathrm{pH} 7.5,10 \mathrm{mM}$ EDTA), were separated on a $15 \%$ SDS-polyacrylamide gel (Bio-Rad, Hercules, CA, USA). After electrophoresis, gel was transferred to nitrocellulose using a semi-dry apparatus (BioRad) according to the manufacturer's instructions. The membrane was incubated for $1 \mathrm{~h}$ at $42^{\circ} \mathrm{C}$ in $5 \%$ bovine serum albumin (BSA; Sigma) in TBST (150 m M NaCl, $20 \mathrm{mM}$ Tris/HCl pH 7.4, 
$0.3 \%$ Tween 20), washed with TBST and incubated for $1 \mathrm{~h}$ at room temperature with goat antiserum specific for UCN (cod. sc-1825, Santa Cruz Biotechnologies, Santa Cruz, CA, USA) diluited $1: 1000$ in TBST containing $1 \%$ BSA. The membrane was washed three times with TBST and than incubated with rabbit anti-goat peroxidase-conjugated antibody (cod. PI-9500 Vector Laboratories, Burlingame, Calif., USA) diluited 1:1000 in TBST containing $1 \%$ BSA for 1 hour at room temperature. Proteins were visualized by an enhanced chemiluminescence kit (Amersham, Bucks, UK) Marker proteins (coloured protein molecular-weight markers; Rainbow, Amersham) were used to estimate the molecular weight of each band.

\section{Immunohistochemistry}

\section{Tissue preparation}

Fresh segments of thymus and cloacal burse were collected from 10-, 30-, 50-, 70-, 90-, 110-, 140- and 170-day-old ducks.

\section{Frozen sections}

The specimens were fixed in $4 \%$ paraformaldehyde in a $0.1 \mathrm{M}$ phosphate-buffered saline (PBS) solution at $\mathrm{pH} 7.5$ for $2-3 \mathrm{~h}$ and placed successively in PBS containing $0.1 \%$ sodium azide and $10 \%$ sucrose and stored overnight at $4^{\circ} \mathrm{C}$. The following day, the samples were transferred to a mixture of PBS-sucrose-azide and OCT compound (Tissue Tek, Elkhart, IN, USA) in a ratio of $1: 1$ for $24 \mathrm{~h}$ before being embedded in $100 \%$ OCT. Coronal sections of 10-20 $\mu \mathrm{m}$ thickness were cut. These sections were treated using a double labelling fluorescence technique. They were preincubated in $2 \%$ Blocking Reagent (Cat No. 1921673 Roche Applied Science, Germany) in PBS containing $0.1 \%$ Triton X-100 (PBS-T) overnight at $4^{\circ} \mathrm{C}$. They were then rinsed three times for $10 \mathrm{~min}$ in PBS-T antisera overnight at $4^{\circ} \mathrm{C}$. The primary antibodies used were as follows: goat polyclonal anti-UCN (final dilution 1:50; cod. sc-1825, Santa Cruz Biotechnologies), mouse monoclonal anti-pan cytokeratin (final dilution 1:1000 cod. C1801 Sigma). After washing with PBS, sections were incubated for $1 \mathrm{~h}$ at room temperature in a $1: 1$ mixture of secondary antibodies that had each an initial dilution of 1:50. The secondary antibodies used were as follows:
FITC-conjugated rabbit anti-goat (cod. 305-095003, Jackson Immunoresearch, West Grove, PA, USA) and rhodamine-conjugated donkey antimouse IgG (cod. 715-025-151 Jackson Immunoresearch). Slides were cover-slipped using immuno-mount aqueous mounting medium and dried at $4^{\circ} \mathrm{C}$ overnight in the dark. To ensure that no cross-reactivity of the secondary detection system occurred, the primary antisera were alternatively omitted in control tests. No cross-reactivity was observed. The specimens were observed by using a Leica TCS SP5 confocal microscope equipped with epifluorescence and the appropriate filter sets for viewing FITC and TRITC.

\section{Paraffin-embedded sections}

The specimens were immediately fixed by immersion in Bouin's fixative (6-24 h) and processed for paraffin embedding in a vacuum, and cut at a thickness of 5-7 $\mu \mathrm{m}$. The avidinbiotin-peroxidase complex $(A B C)$ method was performed with the Vectastain $A B C$ kit (cod. PK 4000, Vector Laboratories). Sections were deparaffinized in xylene and hydrated in a graded solution of ethanol. After the quenching of endogenous peroxidase activity in water containing $0.3 \%$ hydrogen peroxide for 30 min, non specific binding was blocked by treatment with $1.5 \%$ normal rabbit serum (S-5000, Vector Laboratories) in $0.01 \mathrm{M}$ PBS (phosphatebuffered saline; $\mathrm{pH} 7.2$ ) for $30 \mathrm{~min}$. A polyclonal goat antiUCN serum (cod. sc-1825, Santa Cruz Biotechnologies) was applied to the sections at a dilution of 1:1000 and each specimen was incubated in a moist chamber overnight at $4^{\circ} \mathrm{C}$. After the sections had been washed three times in PBS, biotinylated rabbit anti-goat IgG (cod. BA 5000, Vector Laboratories) was applied at a dilution of $1: 200$. The sections were again incubated for 30 min at room temperature. Freshly prepared $A B C$ reagent was applied and incubated for 30 min after three washes in PBS. The localization of UCN was visualized by incubating the sections for $5 \mathrm{~min}$ in freshly prepared diaminobenzidine-nickel solution (cod. SK 4100, Vector Laboratories). The specificity of the immunoreactions was tested by replacing the primary antibody with buffer. No immunoreaction was detected in control tests. The specificity of the primary antibody anti-UCN was tested by adsorption the primary antibody with excess (up to $50 \mu \mathrm{g} / \mathrm{mL}$ in the final dilution) homologous antigen peptide (cod. SC-1825 P Santa Cruz Biotechno- 
logies). The slides of the examinated organs were independently evaluated by two observers by using a Leica DMRA2 microscope and scored according to the density of immunopositivities and intensity of immunoreactions.

\section{Quantitative study}

In the cloacal burse, immunoreactive and negative follicles were counted from ducks in different age periods and the percentage of the immunoreactive follicles was calculated. In the cloacal burse and thymus of different age groups, the density of UCN-ir was determinated by evaluating the area occupied by ir-cells. The area was assessed by quantitative image analysis with the public domain NIH Image J software (http://rsb.info. nih.gov/nih-image/). Measure-ments were made on ten serial sections (one every ten) for each specimen. In the cloacal burse, ten randomly selected ir-follicles per section were measured. In the thymus, ten randomly ir-lobules per section were measured. The area occupied by UCN-ir structures were manually delimited and the percentage of immunoreactivity was calculated upon the total area occupied by burse follicles or thymic lobules. Data were expressed as mean \pm S.D., where $n=$ numbers of animals. The significance of the differences across age groups was evaluated by analysis of variance and by StudentNewman-Keuls's Test for multiple comparisons. A value of $p \leq 0.05$ was considered significant. The evaluation was done esclusively on paraffinembedded sections processed with $A B C$ method.

\section{Results}

\section{Western blot analysis}

The results of the Western blot analysis are shown in Figure 1. Tissue extracts from the thymus (data not shown), cloacal burse, frog and rat brain and the synthetic peptide UCN reacted with the anti-UCN antibody, while the syntetic peptide CRF did not react. The antiserum recognised two protein bands from homogenates, one weighing about $16.0 \mathrm{kDa}$ and another about $6.5 \mathrm{kDa}$.

\section{Immunohistochemistry and co-localization studies}

UCN-like-ir was observed in both thymus and cloacal burse in each of the examined age groups. UCN-like-ir was localized in the cortico- medullary and medullary reticular epithelial (REC) cells (Figure 2b; $4 a, b, c$ ). In addition, UCN-like-ir was localized in the follicle associated epithelium (FAE) (Figure $2 a, c, c 1$ ), in the FAE supporting and in the interfollicular basal epithelial cells (Figure 2c).

The REC were stellate in morphology and formed a network showing an apparent continuation with the cortico-medullary epithelium (Figure 2b; $4 a, b, c$ ) and the FAE (Figure 2c). UCN/CYT colocalization studies (Figure $2 \mathrm{~d}-\mathrm{i}$ ) showed that UCN-like-ir completely colocalized with CYT-ir in the REC, in the cortico-medullary epithelium, in the FAE, in the FAE supporting cells and in the interfullicular basal epithelial cells. In the thymus, UCN-like-ir was observed in medullary epithelial cells (Figure $3 a$ ). These cells were stellate in morphology (Figure $3 b$ ) and were primarily located in the zone separating the cortex from the medulla (Figure $3 \mathrm{a}$ ) and around the thymic corpuscles (Figure $3 \mathrm{C}$ ). UCN/CYT colocalization studies showed that UCN-like-ir was expressed in CYT-ir cells (Figure 3d-f).

\section{Quantitative results}

In the cloacal burse the percentage of UCN-like immunoreactive follicles was more than $90 \%$ in all the examined age groups (Figure $4 a, b, c$ ). The differences in the percentage of ir-follicles among

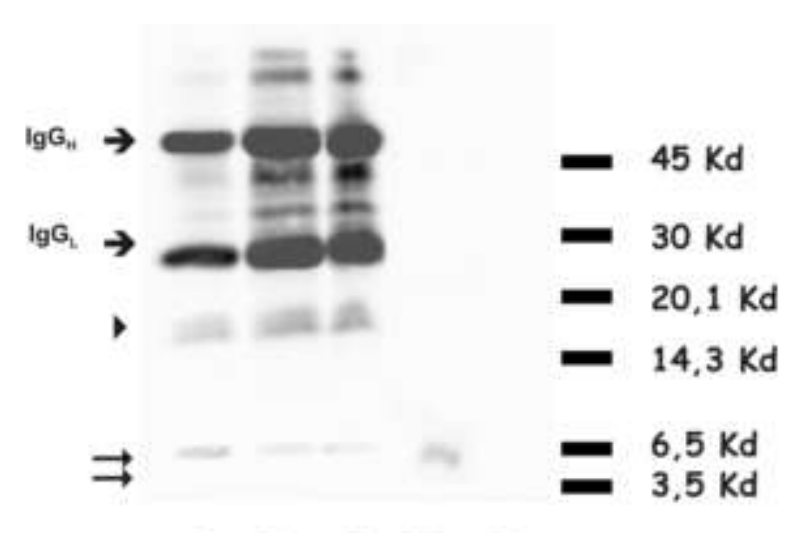

A B C D E 
the groups were not statistically significant (Figure 5). In the cloacal burse, a significant and progressive increase in the percentage of the immunoreactive areas was observed between the age groups up until 140 days (Figure 6 A). After this stage, a decrease was observed. In the thymus, a significant difference in the UCN-ir area was observed between the first (T10) and the second (T30) stages. After 30 days no differences were observed (Figure 6 B).

\section{Discussion}

Western blot analysis showed that the antimammalian UCN antiserum used in the present study recognized, in the duck cloacal burse and thymus, two protein bands having, respectively, a molecular weight of about 16.0 and $6.5 \mathrm{kDa}$. The first protein is compatible with the UCN precursor which is a 122-amino acid protein. The second is compatible with the putative 40-amino acid mature peptide of mammalian UCN (Donaldson et al. 1996; Vaughan et al. 1995). The antiserum
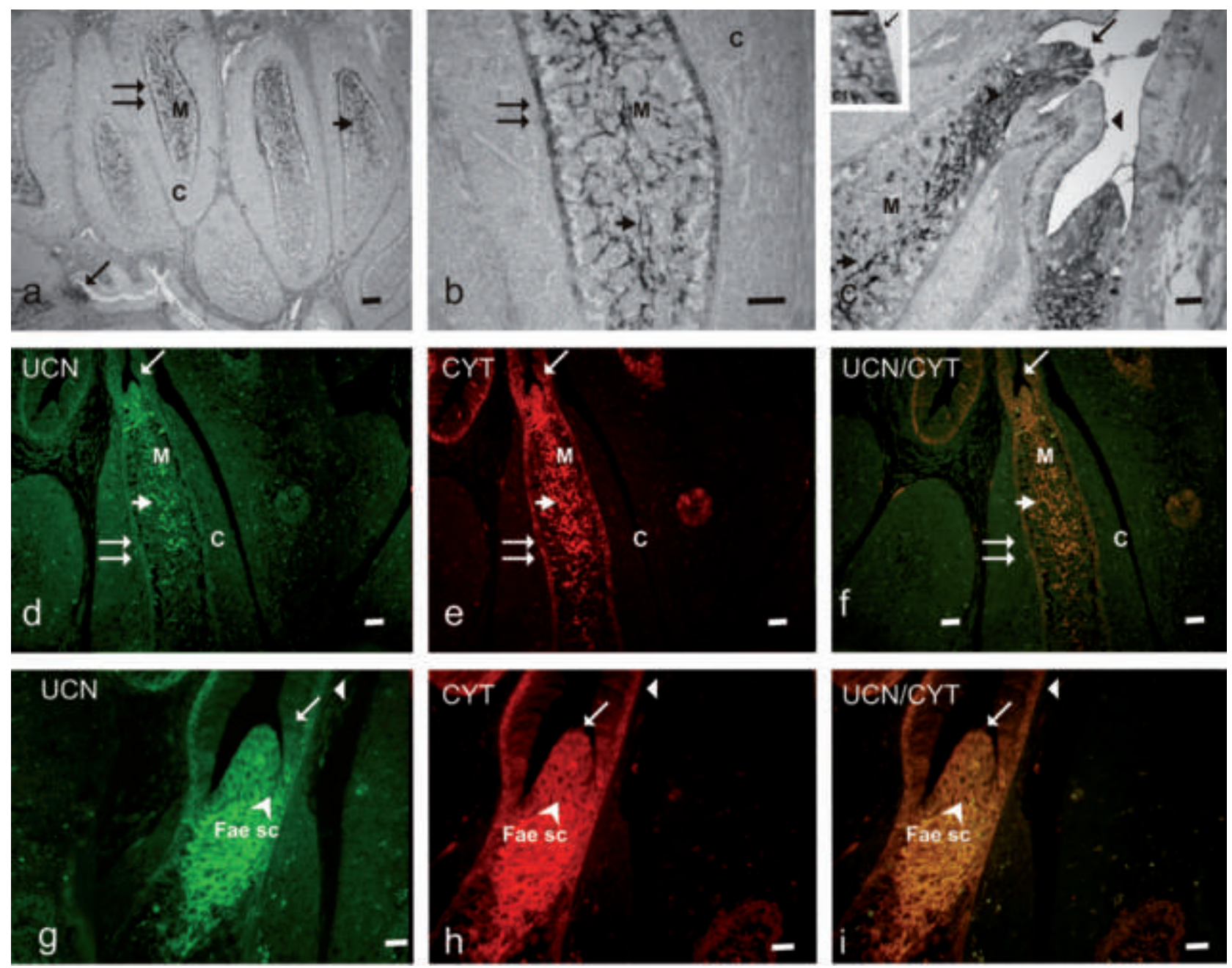

Figure 2. Immunohistochemical localization of UCN-like in the duck cloacal burse of 140 day old animals. UCN-like-ir was found in the follicles in all the examined age groups (a). UCN-like-ir was observed in the cortico-medullary and medullary reticular epithelial cells (b). UCN-like-ir was also localized in the follicle associated epithelium (FAE) (c1), in the FAE supporting and in the interfollicular basal epithelial cells (c). UCN-like/CYT colocalization studies (d-i) showed that UCN-like-ir completely colocalized with CYT-ir in the REC, in the cortico-medullary epithelium, in the FAE, in the FAE supporting cells and in the interfullicular basal epithelial cells. M, Medulla; C, Cortex; $\uparrow$, FAE; $\uparrow \uparrow$, Cortico-medullary epithelium; $\uparrow$, Medullary reticular epithelium; $A$, FAE sc, FAE supporting cells; 4 , interfullicular basal epithelial cells. Bar $=\mathbf{5 0} \mu \mathrm{m}$. Paraffin embedded sections. 

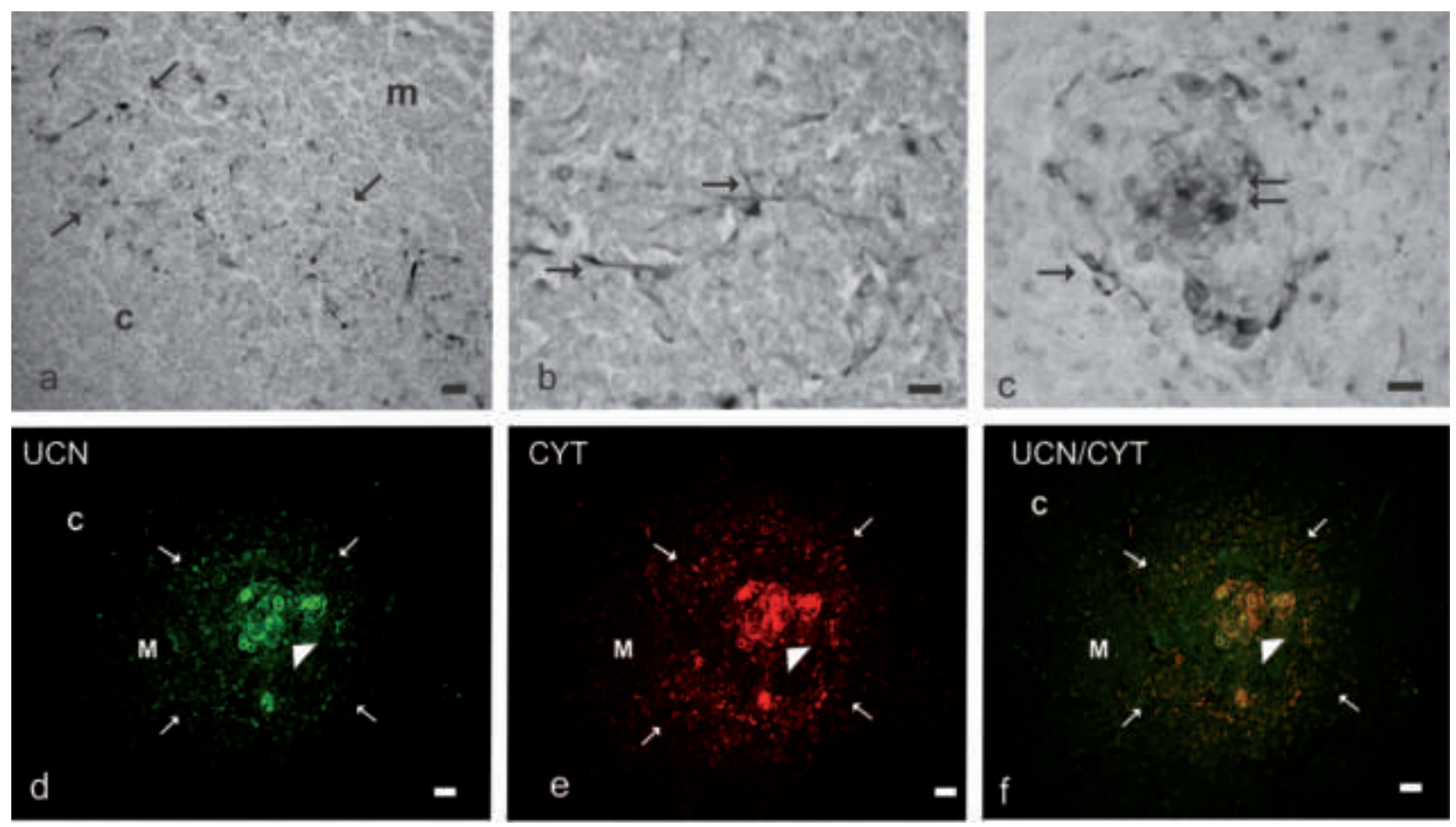

Figure 3. Immunohistochemical localization of UCN-like in the duck thymus of 140 day old animals. UCN-like-ir was observed in medullary epithelial cells (a). These cells were stellate in morphology (b) and were primarily located in the zone separating the cortex from the medulla (a) and around the thymic corpuscles (c). UCN-like/CYT colocalization studies showed that UCN-like-ir was expressed in CYT-ir cells (d-f). M, Medulla; C, Cortex; $\uparrow$, Medullary thymic epithelial cells; $\mathbf{A}$, thymic corpuscle. Bar= $50 \mu \mathrm{m}$. Paraffin embedded sections.
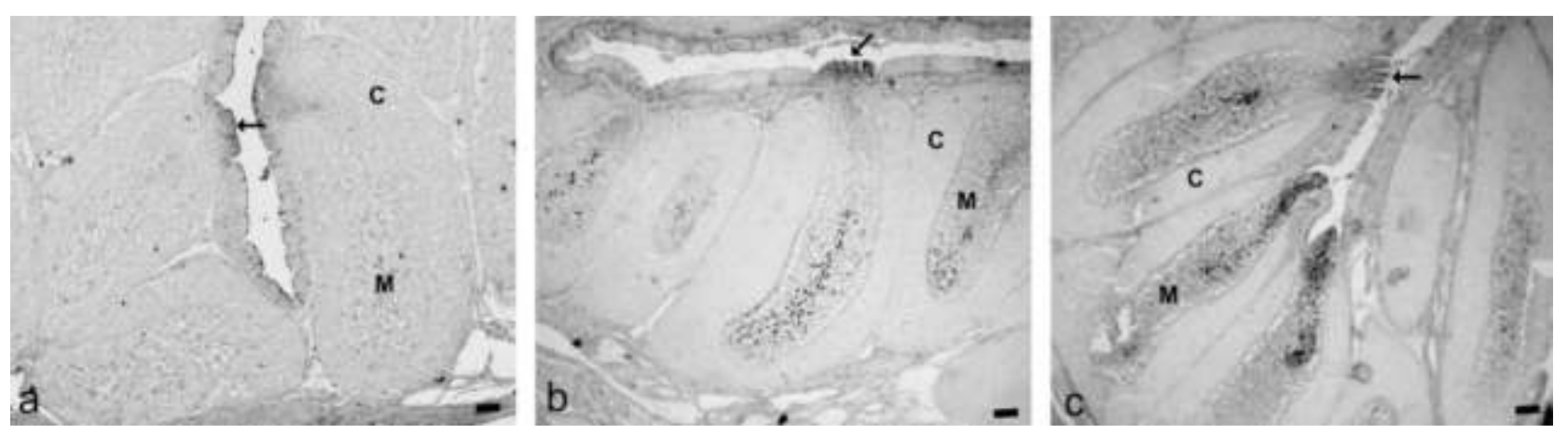

Figure 4. Immunohistochemical localization of UCN-like in the duck cloacal burse of 10-70-140 day old animals. UCN-like-ir was found in the follicles in all the examined age groups $(a, b, c)$. UCN-like-ir was observed in the cortico-medullary and medullary reticular epithelial cells $(a, b, c)$. UCN-like-ir was also localized in the follicle associated epithelium (FAE) (c). M Medulla; C Cortex; $\uparrow$,FAE; Bar= $50 \mu \mathrm{m}$. Paraffin embedded sections.

also recognized a UCN-like protein in both frog and rat brains, suggesting that UCN is conserved among vertebrates (Boorse et al., 2005). The antiserum did not react with the syntetic peptide CRF, thus indicating that it is specific for UCN.

Up until now, the present paper is the first report regarding the presence of UCN in avian tissues outside the CNS. In mammals, UCN expression has been observed in adipose tissue (Seres et al., 2004), heart (Nishikimi et al., 2000), enteric plexus (Harada et al., 1999), testis and kidney (Kageyama et al., 1999), placenta (Petraglia et al., 1996) and adrenals (Fukuda et al., 2005), and has been addressed to regulate a variety of functions (for reviews of the UCN functions in mammals see Oki and Sasano, 2004 and Fekete and Zorrilla, 2007). Among non-mammalian vertebrates, UCN has been found to be widely expressed in amphibians (Boorse et al., 2005), suggesting a potential for diverse actions in 


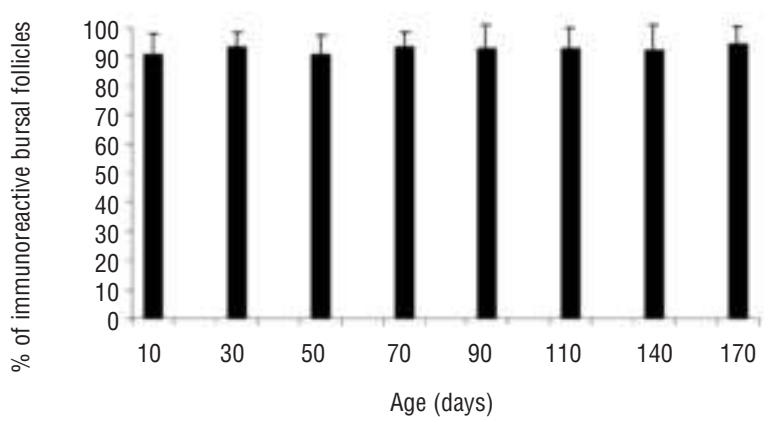

Figure 5. Percentage of Urocortin-like-immunoreactive follicles in the cloacal burse of the duck on the total as function of age. In the cloacal burse the values were not significant in all ages. $n=$ 5 animals; a value of $p<0.01$ was considered significant.
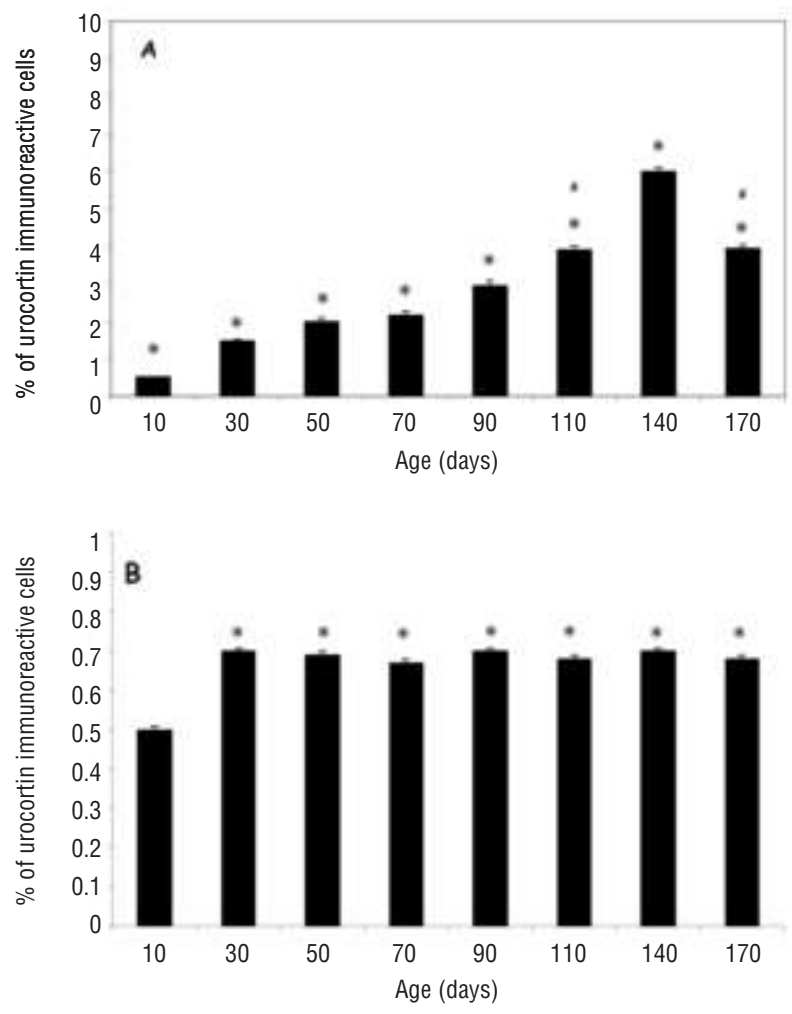

Figure 6. Percentage of area occupied by Urocortin-likeimmunoreactive cells in the cloacal burse (A) and thymus (B) of the duck as function of age. In the cloacal burse $\left({ }^{\star}\right) p<0.01$ was significant in all ages. (\#) $p=0.72$ for 110 day-old duck vs 170 day-old duck. In the thymus $\left({ }^{*}\right) p<0.01$ was significant vs 10 dayold duck. $n=5$ animals; a value of $p<0.01$ was considered significant(*). In the cloacal burse $(*) p<0.01$ was significant in 10 days compared to $30,50,70,90,110,140$ and 170 days, was significant in $\mathbf{3 0}$ days compared to $10,50,70,90,110,140$ and 170 days, was significant in 50 days compared to $10,30,70,90$, $\mathbf{1 1 0}, \mathbf{1 4 0}$ and $\mathbf{1 7 0}$ days, was significant in $\mathbf{7 0}$ days compared to $10,30,50,90,110,140$ and 170 days, was significant in 90 days compared to $10,30,50,70,110,140$ and 170 days, was significant in 110 days compared to $10,30,50,70,90$ and 140 days was significant in 170 days compared to $10,30,50,70,90$ and 140 days. (\#) $p=0,72$ for 110 day-old duck vs 170 day-old duck. In the thymus $\left(^{*}\right) p<0.01$ was significant in $30,50,70,90,110$, 140 and 170 days only vs 10 day-old duck. amphibian tissue maintenance and functions. However, the only example of a role for UCN outside the CNS in a non-mammalian vertebrate is that UCN, like CRF, is cytoprotective in tadpole tail (Boorse et al., 2006).

In mammals, UCN is widely expressed in the lymphoid organs. UCN mRNA has been found in the rat spleen and thymus (Kageyama et al. 1999; Baigent and Lowry, 2000). In addition, UCN-ir and mRNA have been found in human lymphocytes and Jurkatt T-lymphoma cells (Bamberger et al., 1998); in synovial cells, lymphocytes, fibroblasts and macrophages of human patients with rheumatoid arthritis (Uzuki et al., 2001); and in human mast cells (Kempuraj et al., 2004). CRF receptor expression, moreover, has been demonstrated in rat spleen and thymus, mouse spleen and in human Jurkatt T-Lymphoma cells (Radulovic et al., 1999; Baigent and Lowry, 2000). It seems likely that UCN as well as CRH are involved in the modulation of the immune response by acting at specific receptors on multiple populations of immunocytes. Converging lines of evidence suggest that immune-derived UCN locally and directly modulates pro-inflammatory responses to perceived environmental insults, with the direction of this effect depending on the tissue or CRF receptor subtype (Muglia et al., 1994; Karalis et al., 1999; Muramatsu et al., 2000; Kohno et al., 2001; Saruta et al., 2004; Slominski et al., 2001; Tache et al., 2004; Tache and Perdue 2004; Theoharides et al., 2004; Wu et al., 2006).

The immunohistochemical results of the present study demonstrated that UCN-like-ir is expressed in both the cloacal burse and thymus of ducks at different ages. Colocalization studies showed that UCN-like-ir was localized in Cytokeratin expressing cells, i.e., epithelial cells.

In the cloacal burse, in particular, UCNlike/CYT-irs were expressed in the corticomedullary and REC. In addition, they were expressed in the FAE, FAE supporting cells, and in the interfollicular basal epithelial cells. All these cells are regarded as having an endodermic origin (Houssaint and Hallet, 1986; Houssaint et. al., 1986). No UCN-like-ir was observed in lymphocytes. These data contrast with those in mammals reporting that UCN is produced by immunocompetent cells. Our data regarding CYT-ir expression agree with those previously reported in other 
avian species (Sanchez-Refusta et al., 1996; Olah and Glick, 1992).

The function of the bursal epithelium is believed to be connected to the maturation of $B$ cells (Ciriaco et al., 2003; Baba \& Okuno, 1976; Heller \& Friedman, 1979; Toivanen \& Toivanen, 1973). In particular, REC cells are addressed to participate with macrophages, dendritic cells and elements of the extracellular matrix in the formation of a bursal microenviroment for lymphoid cell maturation (Glick, 1995). During the last decade, it was suggested that bursal medullary REC might be a source of bursin (Audhya et al., 1986; Viamontes et al., 1989), a peptide which selectively induces the differentiation of committed Blymphocyte precursor cells (Audhya et al., 1986). The presence of UCN-like-ir in bursal epithelial cells suggests a role for this peptide in the bursal lymphoid cell maturation. UCN produced by epithelial cells may act in a paracrine manner in regulating the activity of lymphoid cells. This hypothesis is supported by the fact that both $\mathrm{CRH}$ receptors are expressed by lymphoid cells (Baigent and Lowry, 2000). UCN, moreover, has been demonstrated to stimulate proliferation of lymphocytes (McGillis et al., 1989). The presence of UCN in FAE, considered an antigen-presenting area (Lupetti and Dolfi, 1982), is relevant in terms of its role in immune responses.

UCN-like-ir, in addition, was observed in the basal cells of the interfollicular epithelium, thus suggesting a role for UCN in regulating the turnover of the interfollicular epithelial cells.

The results of the quantitative analysis showed that the percentage of UCN-like ir areas significantly and progressively increased within the follicles up until 140 days of age. This partially agrees with results observed in the chicken where immunoreactivity to POMC-derived peptides was observed in follicles from 2 months on (Franchini and Ottaviani, 1999). Our findings indicate a physiological role of UCN during both the growing and involutive periods. Involution of the cloacal burse in ducks has been reported to start around 90 days of age (Gille and Salomon, 1999). The presence of an increasing UCN-like immunoreactivity after this time suggest that UCN, in particular, acts as a factor in regulating the mechanisms which control involutive processes. Findings in mammalian and non-mammalian vertebrate tissues have shown that $\mathrm{CRH}$ and related peptides have important cytoprotective and proliferative effects (Brar et al., 2000, 1999; Fox et al., 1993; Radulovic et al., 2003; Boorse et al., 2006). The decrease of UCN-like expression after 140 days is consistent with a rapid progression of the involutive process after this time.

No differences were found regarding the percentage of ir-follicles between the age groups, thus suggesting that the number of follicles showing UCN-like-ir is not influenced by age.

In the thymus, UCN-like-ir was expressed in CYT-ir medullary cells in all the examined age groups, suggesting a physiological role for UCN during thymic maturation. This is in agreement with findings describing the distribution of $\mathrm{CRH}-\mathrm{ir}$ in the thymus of the chicken and other mammalian (rat) and non-mammalian (fish and frog) vertebrates (Ottaviani et al., 1998). In the chicken, however, immunoreactivity to $\mathrm{CRH}$ has been reported to be expressed also in interdigitating vimentin expressing cells, in addition to CYT-ir epithelial cells. Both these cell types have also been reported to express POMC-derived peptides, cytokines and cortisol-like molecules (Franchini and Ottaviani, 1999; Franchini et al., 1995; Ottaviani et al., 1995, 1997, 1998). As a result, the thymus has been addressed to constitute a well defined structure that always present neuroendocrine cells which are capable of producing a multitude of conserved molecules related to the stress response. Thymic epithelial cells, moreover, are addressed to be important elements in creating an appropiate environment for thymic lymphocyte differentiation and maturation (Kendall 1980, 1991; Ciriaco et al., 2003). Similarly to the hypothesis regarding the bursa, thymic epithelial UCN-like producing cells may act in a paracrine manner to regulate the differentiation and maturation of thymic lymphoid cells. It has been shown that apoptosis occurrs in the same thymic areas in which neuroendocrine thymic epithelial cells are found (Ottaviani et al., 1997), thus indicating that these neuroendocrine cells play a role in the mechanism involved in the selection of thymic lymphocytes. In the thymus, quantitative studies showed a significant increase of the UCN like-ir between the 10 and 30 day stages. From 30 days on, the percentage of UCN like-ir did not change. These data indicate that the role played by UCN in the thymic maturation is less relevant in the first 10 days. In conclusion, the results of the present study show 
that UCN like-ir is expressed in the primary lymphoid organs of the duck at different age, and is localized in CYT-ir epithelial cells. UCN may play an important role in the differentiation and maturation of lymphoid cells and in regulating the mechanisms which control the growth and involution of both the thymus and cloacal burse.

\section{References}

Audhya T, Kroon D, Heavner G, Viamontes G, Goldstein G. Tripeptide structure of bursin, a selective B-cell-differentiating hormone of the bursa of fabricius. Science 1986;231:997-9.

Baba T, Okuno Y. Effect of bursa Fabricius extracts on antibody production in bursectomized or bursal cell autografted chickens. Immunology 1976;31:533-9.

Baigent SM. Peripheral corticotropin-releasing hormone and urocortin in the control of the immune response. Peptides 2001;22:809-20. Review.

Baigent SM, Lowry PJ. mRNA expression profiles for corticotrophinreleasing factor (CRF), urocortin, CRF receptors and CRF-binding protein in peripheral rat tissues. $\mathrm{J}$ Mol Endocrinol 2000;25:43-52.

Bamberger CM, Wald M, Bamberger AM, Ergun S, Beil FU, Schulte HM. Human lymphocytes produce urocortin, but not corticotropinreleasing hormone, J Clin Endocrinol Metab 1998;83:708-711.

Boorse GC, Denver RJ Widespread tissue distribution and diverse functions of corticotropin-releasing factor and related peptides. General and Comparative Endocrinology 2006;146:9-18.

Boorse GC, Crespi EJ, Dautzenberg FM, Denver RJ. Urocortins of the South African clawed frog, Xenopus laevis: conservation of structure and function in tetrapod evolution, Endocrinology 2005;146: 4851-60.

Boorse GC, Kholdani CA, Seasholtz AF, Denver RJ. Corticotropinreleasing factor is cytoprotective in Xenopus tadpole tail: Integration of ligand, receptor and binding protein in tail muscle cell survival. Endocrinology 2006;147:1498-507.

Brar BK, Jonassen AK, Stephanou A, Santilli G, Railson J, Knight RA, et al. Urocortin protects against ischemic and reperfusion injury via a MAPK-dependent pathway, J Biol Chem 2000;275:8508-14.

Brar BK, Stephanou A, Okosi A, Lawrence KM, Knight RA, Marber $\mathrm{MS}$, et al. CRH-like peptides protect cardiac myocytes from lethal ischaemic injury, Mol Cell Endocrinol 1999;158:55-63.

Calle M, Corstens GJ, Wang L, Kozicz T, Denver RJ, Barendregt HP, et al. Evidence that urocortin I acts as a neurohormone to stimulate alpha-MSH release in the toad Xenopus laevis. Brain Res 2005; 1040:14-28.

Cavani JA, Reiner A, Cuthbertson SL, Bittencourt JC, Toledo CA. Evidence that urocortin is absent from neurons of the EdingerWestphal nucleus in pigeons. Braz J Med Biol Res 2003;36:1695700 .

Chalmers DT, Lovenberg TW, Grigoriadis DE, Behan DP, De Souza EB. Corticotrophin-releasing factor receptors: from molecular biology to drug design. Trends Pharmacol Sci 1996;17:166-172.

Ciriaco E, Píñera PP, Díaz-Esnal B, Laurà R. Age-related changes in the avian primary lymphoid organs (thymus and bursa of Fabricius). Microsc Res Tech 2003;62:482-7.

Cunha RP, Reiner A, Toledo CA. Involvement of urocortinergic neurons below the midbrain central gray in the physiological response to restraint stress in pigeons. Brain Res 2007;1147:175-83.

Donaldson CJ, Sutton SW, Perrin MH, Corrigan AZ, Lewis KA, Rivier $\mathrm{JE}$, et al. Cloning and characterization of human urocortin. Endocrinology 1996;137:2167-70.

Fekete EM, Zorrilla E P. Physiology, pharmacology, and therapeutic relevance of urocortins in mammals: Ancient CRF paralogs. Frontiers in Neuroendocrinology 2007;28:1-27.

Fox MW, Anderson RE, Meyer FB. Neuroprotection by corticotropinreleasing factor during hypoxia in rat brain. Stroke 1993;24:10725.
Franchini A, Ottaviani E, Franceschi C. Presence of immunoreactive pro-opiomelanocortin-derived peptides and cytokines in the thymus of an anuran amphibian Rana esculenta. Tissue Cell 1995;27: 2637.

Franchini A, and Ottaviani E. Immunoreactive POMC-Derived Peptides and Cytokines in the Chicken Thymus and Bursa of Fabricius Microenvironments: Age-Related Changes Journal of Neuroendocrinology 1999;11;685-92.

Fukuda T, Takahashi K, Suzuki T, Saruta M, Watanabe M, et al. Urocortin 1, urocortin 3/stresscopin, and corticotropin-releasing factor receptors in human adrenal and its disorders. J Clin Endocrinol Metab 2005;90:4671-8.

Gille U, Salomon FV. Growth of the cloacal bursa (bursa of Fabricius) and spleen in ducks. Anat Histol Embryol 1999;28:229-33.

Glick B. Embryogenesis of the bursa of Fabricius: stem cell, microenvironment, and receptor-paracrine pathways. Poult Sci 1995;74: 419-26.

Harada S, Imaki T, Naruse M, Chikada N, Nakajima K, Demura H. Urocortin mRNA is expressed in the enteric plexus of the rat, Neurosci Lett 1999;267, 125-8.

Heller DE, Friedman AR. The effect of crude bursa of Fabricius extracts on the humoral immune response and its recovery in bursectomized chickens. Dev Comp Immunol 1979;3:667-81.

Houssaint E, Diez E, Hallet MM. The bursal microenvironment: phenotypic characterization of the epithelial component of the bursa of Fabricius with the use of monoclonal antibodies. Immunology 1986;58:43-9

Houssaint E, Hallet MM. The follicle-associated epithelium in the bursa of Fabricius cell origin studied by means of quail-chick chimeras and monoclonal antibodies. J Leukoc Biol 1986;40:46977.

Kageyama K, Bradbury MJ, Zhao L, Blount AL, Vale WW. Urocortin messenger ribonucleic acid: tissue distribution in the rat and regulation in thymus by lipopolysaccharide and glucocorticoids. Endocrinology 1999;140:5651-8.

Karalis KP Kontopoulos E, Muglia LJ, Majzoub JA. Corticotropinreleasing hormone deficiency unmasks the proinflammatory effect of epinephrine. PNAS 1999;96:7093-97.

Kempuraj D, Papadopoulou N, Stanford EJ, Christodoulou S, Madhappan B, Sant GR, et al. Increased numbers of activated mast cells in endometriosis lesions positive for corticotropin-releasing hormone and urocortin. Am J Reprod Immunol 2004;52:267-75.

Kendall MD. Functional anatomy of the thymic microenvironment. J. Anat 1991;177:1-29.

Kendall MD. Avian thymus glands: a review. Dev Comp Immunol 1980;4:191-209.

Kohno M, Kawahito $Y$, Tsubouchi $Y$, Hashiramoto A, Yamada R, Inoue $\mathrm{KI}$, et al. Urocortin expression in synovium of patients with rheumatoid arthritis and osteoarthritis: relation to inflammatory activity, $J$. Clin. Endocrinol. Metab 2001;86:4344-52.

Kozicz T, Arimura A, Maderdrut JL, Lazar G. Distribution of urocortin-like immunoreactivity in the central nervous system of the frog Rana esculenta, J. Comp. Neurol. $2002 ; 453$, 185-198.

Latchman DS. Urocortin protects against ischemic injury via a MAPK-dependent pathway. Trends Cardiovasc 2001;11:167-9.

Lewis K, Li C, Perrin MH, Blount A, Kunitake K, Donaldson C, et al. Identification of urocortin III an additional member of the corticotropin-releasing factor (CRF) family with high affinity for the CRF2 receptor. Proc Natl Acad Sci USA 2001;98:7570-5.

Lupetti M, Dolfi A. A contribution to the study of the lymphoid-follicle associated epithelial cells. Z mikrosk-anat Forsch 1982;96:214-20.

McGillis JP, Park A, Rubin-Fletter P, Turck, C, Dallman MF, Payan, DG. Stimulation of rat B-lymphocyte proliferation by corticotropin releasing factor. J Neurosci Res 1989;23:346-52.

Muglia LJ, Jenkins NA, Gilbert DJ, Copeland NG, Majzoub JA. Expression of the mouse corticotropin-releasing hormone gene in vivo and targeted inactivation in embryonic stem cells. J Clin Invest 1994; $93: 2066-72$.

Muramatsu Y, Fukushima K, Iino K, Totsune K, Takahashi K, Suzuki T., et al. Urocortin and corticotropin-releasing factor receptor expression in the human colonic mucosa. Peptides 2000;21:1799-809.

Nishikimi T, Miyata A, Horio T, Yoshihara F, Nagaya N, Takishita S, et al. Urocortin, a member of the corticotropin-releasing factor family, in normal and diseased heart. Am J Physiol Heart Circ hysiol 
2000;279:H3031-H3039.

Oki Y, Sasano H. Localization and physiological roles of urocortin Peptides 2004;25:1745-9.

Olah I, Glick B. Follicle-associated epithelium and medullary epithelial tissue of the bursa of fabricius are two different compartments. Anat Rec 1992;233:577-87.

Ottaviani E, Capriglione T, Franceschi C. Invertebrate and vertebrate immune cells express pro-opiomelanocortin POMC mRNA. Brain Behav Immun 1995;9:1-8.

Ottaviani E, Franchini A, Franceschi C. Evolution of neuroendocrine thymus: studies on POMC-derived peptides, cytokines and apoptosis in lower and higher vertebrates. Journal of Neuroimmunology. 1997; 72:67-74.

Ottaviani E, Franchini A, Franceschi C. Presence of immunoreactive corticotropin-releasing hormone and cortisol molecules in invertebrate haemocytes and lower and higher vertebrate thymus. Histochemical Journal 1998;30:61-7.

Petraglia F, Florio P, Gallo R, Simoncini T, Saviozzi M, Di Blasio AM, et al. Human placenta and fetal membranes express human urocortin mRNA and peptide. J Clin Endocrinol Metab 1996;81:380710

Radulovic M, Hippel C, Spiess J. Corticotropin-releasing factor (CRF) rapidly suppresses apoptosis by acting upstream of the activation of caspases. J. Neurochem 2003;84:1074-85.

Radulovic J, Ruhmann A, Liepold T, Spiess J. Modulation of learning and anxiety by corticotropin-releasing factor (CRF) and stress: differential roles of CRF receptors 1 and 2. J Neurosci 1999;19. 5016-25.

Reyes TM, Lewis K, Perrin MH, Kunitake KS, Vaughan J, Arias CA, et al. Urocortin II: A member of the corticotropin-releasing factor (CRF) neuropeptide family that is selectively bound by type 2 CRF receptors. Proc Natl Acad Sci USA 2001;98:2843-8.

Sanchez-Refusta F, Ciriaco E, Germanà A, Germanà G, Vega JA. Agerelated changes in the medullary reticular epithelial cells of the pigeon bursa of Fabricius. Anat Rec 1996;246:473-80.

Saruta M, Takahashi K, Suzuki T, Torii A, Kawakami M, Sasano H. Urocortin 1 in colonic mucosa in patients with ulcerative colitis. $J$ Clin Endocrinol Metab 2004;89:5352-61.

Seres J, Bornstein SR, Seres $P$, Willenberg HS, Schulte KM Scherbaum WA, et al. Corticotropin-releasing hormone system in human adipose tissue. J Clin Endocrinol Metab 2004;89:965-70.

Slominski A, Wortsman J, Pisarchik A, Zbytek B, Linton EA, Mazurkiewicz JE, et al. Cutaneous expression of corticotropinreleasing hormone $(\mathrm{CRH})$, urocortin, and $\mathrm{CRH}$ receptors. FASEB J 2001;15:1678-93.

Tache Y, Martinez V, Wang L, Million M. CRFI receptor signaling pathways are involved in stress-related alterations of colonic function and viscerosensitivity: implications for irritable bowel syndrome. $\mathrm{Br}$ J Pharmacol 2004;141:1321-30.

Tache $Y$, Perdue $\mathrm{MH}$. Role of peripheral CRF signalling pathways in stress-related alterations of gut motility and mucosal function, Neurogastroenterol. Motil 2004;16:137-42.

Theoharides TC, Donelan JM, Papadopoulou N, Cao J, Kempuraj D, Conti P. Mast cells as targets of corticotropin-releasing factor and related peptides. Trends Pharmacol Sci 2004;25:563-8.

Toivanen P, Toivanen A. Bursal and postbursal stem cells in chicken. Functional characteristics. Eur J Immunol 1973;3:585-95.

Turnbull AV, Vaughan J, Rivier JE, Vale WW, Rivier C. Urocortin is not a significant regulator of intermittent electrofootshock -induced adrenocorticotropin secretion in the intact male rat. Endocrinology 1999; 140:71-8.

Uzuki M, Sasano H, Muramatsu, Y, Totsune K, Takahashi K, Oki Y, Iet al. Urocortin in the synovial tissue of patients with rheumatoid arthritis. Clin Sci (Lond) 2001;100577-89.

Vaughan J, Donaldson C, Bittencourt J, Perrin MH, Lewis K, Sutton S, et al. Urocortin, a mammalian neuropeptide related to fish urotensin I and to corticotropin-releasing factor. Nature 1995;378:287-92.

Viamontes GI, Audhya TK, Babu U, Goldstein G. Immunohistochemical localization of bursin in epithelial cells of the avian bursa of Fabricius. J Histochem Cytochem 1989;37:793-9.

Wu Y, Zhou H, Xu Y, Li S. Enhanced expression of urocortin in lung tissues of rats with allergic asthma. Biochem Biophys Res Commun 2006;341:532-40.

Zhang R, Nakanishi T, Ohgushi A, Ando R, Yoshimatsu T, Denbow DM, et al. Suppression of food intake induced by corticotropin-releasing factor family in neonatal chicks. Eur J Pharmacol 2001;427:3741. 